\title{
Eidorfe Moreira: uma introdução
}

Maria Stella Faciola Pessôa Guimarães Núcleo de Altos Estudos Amazônicos

Universidade Federal do Pará

Em sua trajetória, com a missão de difundir trabalhos científicos, o Boletim do Museu Paraense Emílio Goeldi. Ciências Humanas tem usado o Dossiê como recurso elogiável, ora colecionando artigos em torno de uma pessoa ou personalidade, ora à volta de temas que despertam amplo interesse de pesquisadores, professores e leitores em geral. Destacam-se, como iniciativas recentes, "Um tributo a Charles Wagley", "Imagem, História e Ciência" e "Metodologia da pesquisa arqueológica". Outras vezes, a revista, de abrangência nacional e internacional, vale-se da seção Memória para reunir textos a partir do legado deixado por um intelectual, como fez em 2011 com Benedito Nunes, nascido em Belém, cidade na qual também faleceu, e nome associado à multíplice obra, sobretudo em filosofia e crítica literária. No atual número, o periódico do Museu Goeldi projeta seu foco na direção de Eidorfe Moreira (1912-1989). O autor nasceu na Paraíba, mas viveu a maior parte de sua vida no Pará, escolhendo a Amazônia como convergência maior de suas reflexões e escrevendo livros e artigos em Belém, onde exerceu o magistério, tanto em colégios da cidade como na Universidade Federal do Pará (UFPA).

Em 1989, após a morte de Eidorfe, foram editadas suas "Obras reunidas", em oito volumes listados a seguir, coletânea amplamente referida neste Dossiê:

Volume 1: "Conceito de Amazônia"; "Sertão: a palavra e a imagem"; "Amazônia: o conceito e a paisagem"; "Alfredo Ladislau"; "Belém e sua expressão geográfica";

Volume 2: "Roteiro bibliográfico do Marajó"; "Estado e ideologia"; "Ideias para uma concepção geográfica da vida";

Volume 3: "Presença do mar na literatura brasileira"; "O fator social na consideração do solo";

Volume 4: "Os sermões que Vieira pregou no Pará"; "Os igapós e seu aproveitamento"; "Visão geossocial do Círio"; "Presença hebraica no Pará"; "Kant como geógrafo"; "O nefelismo de El Greco"; "As letras jurídicas no Pará";

Volume 5: "Os igapós e seu aproveitamento" (nova edição); "Para a história da Universidade Federal do Pará"; "A educação moral, cívica e religiosa no Pará";

Volume 6: "O livro didático paraense"; "Obras escolares paraenses de história"; "Influências amazônicas no Nordeste";

Volume 7: "Geografias mágicas";

Volume 8: Publicações avulsas ("Pequena história de uma biblioteca particular"; "Um motivo para a rosa"; "Um soldado anônimo de muitas lutas"; "Dom Quixote e o problema do conhecimento"); "Seara amazônica"; "Os fundamentos geográficos do planejamento"; "Uma filosofia em termos geográficos".

Os oito volumes enfeixam a maior parte da produção intelectual de Eidorfe, mas há outros trabalhos do autor, como a vasta publicação em revistas e jornais paraenses - grande presença está em "A Província do Pará". Citam-se

GUIMARÃES, Maria Stella Faciola Pessôa. Eidorfe Moreira: uma introdução. Boletim do Museu Paraense Emílio Goeldi. Ciências Humanas, Belém, v. 10, n. 3, p. 567-568, set.-dez. 2015. DOI: http://dx.doi.org/10.1590/1981-81222015000300002.

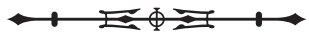


amostras: "O romance amazônico de Júlio Verne"; "Mundividência em termos de delírio: a página por excelência de Machado de Assis"; "Capistrano de Abreu e a Amazônia"; "Colégio Estadual Paes de Carvalho: forja e centro nucleador da cultura paraense"; "Belém do futuro e sua moldura insular"; "Sentido econômico da fundação de Belém"; "O Museu Goeldi e a Amazônia"; "La Condamine e a Amazônia".

Destarte, a obra de Eidorfe desconsidera barreiras disciplinares, espraiando-se pelas áreas mais diversas do conhecimento. Este Dossiê procura evidenciar tal poligrafia. Assim, inicialmente, Antonio de Oliveira Júnior, apoiado em recursos da geografia e do planejamento regional, examina a contribuição de Eidorfe para conceituar a Amazônia como paisagem e região. Belém, na sua maior superfície, é constituída de ilhas, sendo a ampla dimensão insular objeto do pensamento de Eidorfe, o que é detalhado por Gutemberg Armando Diniz Guerra. Depois, Ivone Maria Xavier de Amorim Almeida, com mais proximidade da sociologia, analisa o escrito de Eidorfe sobre o Círio de Nossa Senhora de Nazaré, realizado anualmente na capital do Pará. A coleção de artigos termina com a mostra de Maria Stella Faciola Pessôa Guimarães e Edna Maria Ramos de Castro, que localizam e analisam, na obra de Benedito Nunes, as referências críticas ao legado de Eidorfe. Como apêndice, compõe essa última exposição, um ensaio de Benedito de 1960, com o título "Imagem do sertão", dedicado ao livro de Eidorfe lançado naquela ocasião.

Cabe, finalmente, registrar que Benedito foi um grande entusiasta do propósito de repor em circulação e debate os livros de Eidorfe, acervo esgotado há muitos anos. Chegamos a conversar várias vezes sobre o assunto, especialmente às proximidades do que seria o $100^{\circ}$ aniversário de Eidorfe, em 2012. Benedito faleceu antes daquele centenário, todavia houve tempo dele nos desafiar ao pensar em voz alta e vislumbrar caminhos. Há muito a fazer, mas alguns planos foram concretizados. Por exemplo, durante o Congresso Eidorfe Moreira, realizado em Belém no citado ano, por iniciativa da Secretaria Municipal de Educação (SEMEC) e da Universidade da Amazônia (UNAMA), quando foi lançada a edição comemorativa de "Ideias para uma concepção geográfica da vida", Nelson Sanjad - então editor deste periódico - começou a pensar na possibilidade de um Dossiê, enfim realidade.

Que a boa leitura dos trabalhos a seguir traga sinais evidentes de que as ideias podem circular, como organismos vivos em travessia, sobremaneira quando criticadas e reconfiguradas!

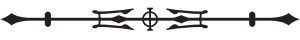

